\title{
\#EdTechHub
}

Realising the potential of technology in education

\section{EdTech in Liberia: A Rapid Scan}

Arjun Upadhyay and Abeba Taddese

EdTech Hub, https://edtechhub.org

Country Scan

2020-06-30

DOI: 10.5281/zenodo.3830953

For enquiries please email helpdesk@edtechhub.org 


\section{About this document}

Recommende Upadhyay, A, and Taddese, A. (2020). EdTech in Liberia: A Rapid Scan. d citation. (EdTech Hub Country Scan No. 01). DOI:

10.5281/zenodo.10.5281/zenodo.3830953. Available from https://docs.edtechhub.org/lib/2HM2SBVM. Available under Creative Commons Attribution 4.0 International,

https://creativecommons.org/licenses/by/4.0/.

Licence. Creative Commons Attribution 4.0 International

https://creativecommons.org/licenses/by/4.0/.

You - dear readers - are free to share (copy and redistribute the material in any medium or format) and adapt (remix, transform, and build upon the material) for any purpose, even commercially. You must give appropriate credit, provide a link to the license, and indicate if changes were made. You may do so in any reasonable manner, but not in any way that suggests the licensor endorses you or your use.

\section{Identifiers. 2405685:2HM2SBVM;10.5281/zenodo.3830951.}

Internal use. g/d/1qyIK1GuntCEL6yQ7zTII2FKpo6ZItArjt63avCF2GHI/edit?ts=5ee8f9 de

Reviewed by Xiaonan Cao, Senior Education Specialist, World Bank; Oni Lusk-Stover, Senior Education Specialist, World Bank; Binta Beatrice Massaquoi, Education Specialist, World Bank; Tihtina Zenebe Gebre, Young Professional, World Bank; Anusha Pudugramam Ramakrishnan, Economist Consultant, World Bank

Notes. $\quad$ The EdTech Hub is supported by UK aid from the UK government; however the views expressed are the views of the authors and do not necessarily reflect views of our donors. 


\section{About this scan}

EdTech Hub country scans explore factors that enable and hinder the use of technology in education. These factors include the policy or vision for EdTech, institutional capacity, private-sector partnerships and digital infrastructure. The scans are intended to be comprehensive but are by no means exhaustive. However, we hope they will serve as a useful starting point for more in-depth discussions about opportunities and barriers in EdTech in specific countries, in this case, Liberia.

This report was originally written in June 2020. It is based primarily on desk research, with quality assurance provided by a country expert. Given how rapidly the educational technology landscape is evolving, the Hub plans to provide periodic updates. Table 1 provides a summary of the situation regarding EdTech in Liberia.

\section{Table 1. EdTech in Liberia: A summary}

\begin{tabular}{|c|c|}
\hline Policies & $\begin{array}{l}\text { - The 2019-2024 National ICT Policy includes provisions for ICT in } \\
\text { education (Government of Liberia, 2019) } \\
\text { - Liberia recently developed an ICT in Education Policy Paper with } \\
\text { support from UNESCO }\end{array}$ \\
\hline Infrastructure & $\begin{array}{l}\text { - } 20 \% \text { of households in Liberia have access to electricity and less than } \\
7 \% \text { have access to the internet } \\
\text { - Only } 14 \% \text { of primary and secondary schools have electricity } \\
\text { - Data on other core ICT-in-education indicators are not available }\end{array}$ \\
\hline $\begin{array}{l}\text { Partners and } \\
\text { initiatives }\end{array}$ & $\begin{array}{l}\text { - Most EdTech initiatives are led by donors and international } \\
\text { organisations and typically use radio and tablet technologies } \\
\text { - The Ministry of Education has used instructional radio programmes at } \\
\text { the pre-primary, primary and junior-high levels in response to school } \\
\text { closures caused by the Ebola epidemic and Covid-19 pandemic }\end{array}$ \\
\hline Covid-19 & $\begin{array}{l}\text { - The Government of Liberia closed all schools closed on March 16, } \\
\text { 2020, affecting approximately } 1.6 \text { million learners at all levels of } \\
\text { education } \\
\text { - The MoE is drafting a Covid-19 Education Response Plan }\end{array}$ \\
\hline
\end{tabular}

\section{Country overview}

Africa's oldest republic, Liberia was founded on July 26,1847 . The country is organised into four regions, 15 counties and 90 administrative districts. There are 16 indigenous ethnic groups in Liberia. The capital, Monrovia, accounts for a third of the country's 4.6 million population.

From 1979 to 2003, intermittent civil war led to an estimated 270,000 deaths with millions more displaced. Liberia is still considered a fragile state despite significant socio-economic growth since 2003 (World Bank, 2018). The country held its first peaceful democratic transition of governments in February 2018 with the election of President George Weah. 
Liberia suffers from widespread poverty. Approximately 70 per cent of the population lives below the World Bank's international extreme poverty line of US $\$ 1.90$ per day. With an HDI score of 0.465, Liberia ranks 176 out of 189 countries surveyed in 2018. There is extreme inequality in wealth, distribution of resources, infrastructure and learning outcomes between the capital and the rest of the country. Liberia's inequality adjusted-HDI score is 0.314 .

Between March 2014 and September 2015, Liberia was ravaged by Ebola. It disrupted businesses and industry, weakened already fragile public health systems, and lowered household income and government revenue. The Ebola epidemic forced the closure of all schools in the country from May 2014 to February 2015. It led to 4,809 deaths.

\section{Education system overview}

The 2011 Education Reform Act is the organising document for the education sector. It frames the Ministry of Education's (MoE) governance structures, management roles and responsibilities at the national, regional, county and administrative levels (World Bank, 2016). The education system is organised in four tiers:

1. Early childhood education (ECE) for children aged 3 to 5 years.

2. Basic education spans nine grades comprising two sub-cycles. The first cycle includes six years of lower basic education (grades 1-6) for children aged 6-11. The second cycle has three years of upper basic education (grades 7-9) for children aged 12-14. Upper basic education is also referred to as Junior High School. Students take the West African Examination Council's (WAEC) exam at the end of grade 9. Students who pass the exam and receive the Liberia Junior High School Certificate Examination are able to continue to Senior High School.

3. Secondary education comprises three years of academic (Senior High School) or technical and vocational education and training (TVET). The end of Senior High School is marked by the WAEC Grade 12 examination.

4. Tertiary education includes certification, diploma, degree and post-graduate programmes offered by teacher education institutes, colleges and universities.

The education sector is governed by the MoE at the national level. At the county and district levels, the sector is governed by the County School Systems that are led by Country School Boards (CSB) and supported by MoE Officers at county and district levels.

The Education Sector Development Committee (ESDC) is the main forum for education-sector coordination and dialogue. The ESDC brings together the MoE and representatives from donor and multilateral agencies, international non-governmental organisations (NGOs) and domestic Civil Society Organisations (CSOs), and the National Teachers Association Union of Liberia (NTAL). The development partners that are represented on the ESDC are the World Bank, the European Union (EU), USAID, and UNICEF. A subset of ESDC actors are members of the Local Education Group (LEG), a group that is focused on operationalisation and decision-making. 


\subsection{Education sector progress and challenges}

Over the past three decades, enrollment in early childhood education, basic education, and secondary education in Liberia has increased nearly five-fold. This increase has been accompanied by the increase in the number of schools and teachers at all levels. The growth in teacher supply has led to a sharp decrease in the pupil-teacher ratio, falling from 49 pupils per teacher in government primary schools in 2007, to 27.6 in 2015. The pupil to trained teacher ratio at the primary level fell from 59:1 in 2007 to 43.5:1 in 2015. According to the 2015 school census, the number of schools increased by almost 1,500 schools in the years following 2007 / 2008 to reach a total of 5,438 in 2015. ${ }^{1}$

Table 2. Gross enrollment ratio (GER) by school level

\begin{tabular}{|l|l|l|}
\hline Education level & $\mathbf{1 9 8 1}$ & $\mathbf{2 0 1 5}$ \\
\hline Early childhood education & 38 & 116 \\
\hline Primary & 53 & 87 \\
\hline Junior High School & 28 & 53 \\
\hline Senior High School & 20 & 39 \\
\hline
\end{tabular}

Private, mission and community schools account for nearly half of enrollment in primary schools. The percentage of private enrollment at junior high and senior high school levels is even higher. The majority of private and religious schools are located in urban areas of four counties (Montserrado, Margibi, Bong and Grand Bassa).

Since 2008 Liberia has seen significant improvements in the Gender Parity Index (GPI) for enrollment at the primary and junior high school levels. Primary GPI increased from 0.88 in 2008 to 0.96 in 2015 (World Bank, 2016: 47). Similarly, the junior high school GPI increased from 0.79 in 2008 to 0.98 in 2015.

Basic education completion and progression rates remain low. Of the population of children who enroll in basic education, only 69 per cent reach grade 6 and 59 make it to grade 9 (Ibid.).

Reaching out-of-school children remains a challenge. Liberia has one of the highest rates of out-of-school children in the world. The rate of primary-aged, out-of-school children in Liberia has increased from 59 per cent in 2011 to 62.3 per cent in 2015 (UNESCO Institute for Statistics, 2020).

\footnotetext{
${ }^{1}$ Data from the 2007 / 2008 school census lists the total number of schools at each level but does not tally the total number of physical schools. However, the World Bank (2016) estimates an increase of 1,500 physical schools since 2007 / 2008.

${ }^{2}$ World Bank (2016), available at

http://documents.shihang.org/curated/zh/481011575583469840/pdf/Liberia-Education-Sector-A nalysis.pdf
} 
Despite the growth of the teacher workforce, many teachers are not qualified and do not receive adequate support. Just over 50 per cent of the teacher workforce has the minimum qualification required to teach at the grade they are teaching. Teachers receive minimal institutional support and teachers in rural areas often walk long distances to collect their salaries, contributing to high absenteeism rates (World Bank, 2016). In addition, teachers face frequent delays in their salary payments (Andalou Agency, 2019; Ministry of Finance and Development Planning, 2019).

Many MoE departments and priorities are severely underfunded. County and district education officers do not receive regular professional development, and the MoE has yet to develop teacher education programmes or guidelines to support staff in executing their job responsibilities (World Bank, 2016).

\subsection{Education Section Plan 2017-2021}

The education sector is guided by the Getting to Best 2017-2021 Education Sector Plan. The plan has a total of nine strategic objectives (or programmes) under the goal to improve the equity, quality and relevance of teaching and student learning in early childhood education, basic education, secondary education, alternative education, TVET and higher education. The goals are to:

1. Improve access to quality early childhood education.

2. Provide quality alternative and accelerated education pathways for overage and out-of-school children and young people.

3. Mainstream gender and school health across the education sector.

4. Ensure that teachers have access to quality instructional materials and assessment tasks.

5. Improve the efficiency, effectiveness and satisfaction of the teaching workforce.

6. Improve the quality and relevance of technical and vocational training.

7. Establish an effective school quality improvement and accountability system.

8. Improve the efficiency and performance of education management systems.

9. Leverage regional and international partnerships and expertise, target market demand for critical skills and increase the efficiency of education expenditure.

\section{EdTech policy and strategy}

Liberia recently developed an ICT education paper policy in partnership with UNESCO. However, very little is known about whether the policy has been endorsed by the MoE and what actions have been taken in implementing the policy. EdTech does not feature in the Getting to Best Education Sector Plan. However, the 2019-2024 National ICT Policy, signed in 2019, includes provisions for ICT in education. Consultations for developing a specific ICT in education policy started in 2019. 


\subsection{National information and communications technology policy}

The 2019-2024 National ICT Policy recognises ICT as a critical tool of the national transformation and development process. It states that

"investing in education, health and other socio-economic development programmes shall yield sustainable results using ICT as a vehicle towards achieving those objectives" (Government of Liberia, 2019: 30).

The National ICT Policy specifically makes provisions for ICT in education and states that the national "e-education strategy" aims to:

1. Encourage all educational institutions to invest in computers and to connect to the Internet.

2. Promote electronic distance learning, training and virtual learning systems to complement and supplement campus-based education and training systems.

3. Develop ICT curricula for all levels of the educational system.

4. Work with the private sector to create affordable packages and schemes under which students, teachers and educational institutions can afford ICT products and services.

5. Develop standards for the certification of ICT professionals.

6. Encourage public and private sector apprenticeship programmes, internship, co-opts and work-study programmes in ICT.

7. Encourage the private sector in its delivery of on-the-job ICT training and retraining programmes.

8. Improve access to e-learning to people with disabilities.

In 2019, the Government of Liberia launched GovNet, Liberia's secure network on which all e-government activities are expected to run (Wilkins, 2019).

\subsection{Information and communications technology in education policy}

Liberia recently completed an ICT in Education Policy. In 2019, the UNESCO office in Liberia, in collaboration with the MoE and in sponsorship by the People's Republic of China, began local consultations with key stakeholders to articulate a national policy on ICT in Education (Front Page Africa, 2019). Little is known about the current status of the ICT policy and whether it has been endorsed by the MoE. Efforts to develop an ICT in education policy is supported by several donors including the World Bank (through the IRISE programme), the EU and UNICEF.

\section{Information and communications technology: infrastructure}

Access to ICT across Liberia is limited. Only 20 per cent of households in Liberia have access to electricity and less than 3 per cent have access to the internet. It is estimated that half of Liberia's population have mobile-cellular subscriptions. Data on ICT in education are poor. Only 6 per cent of primary and secondary schools have electricity 
UNESCO Institute for Statistics (2015). Data on core ICT in education indicators are not available.

Table 3. Core ICT in Education Indicators ${ }^{3}$

\begin{tabular}{|l|l|}
\hline Indicators & N/A \\
\hline $\begin{array}{l}\text { Proportion of schools with a radio used for educational } \\
\text { purposes (for ISCED levels 1-3) }\end{array}$ & N/A \\
\hline $\begin{array}{l}\text { Proportion of schools with a TV used for educational purposes } \\
\text { (for ISCED levels 1-3) }\end{array}$ & N/A \\
\hline $\begin{array}{l}\text { Proportion of schools with a telephone communication facility } \\
\text { (for ISCED levels 1-3) }\end{array}$ & N/A \\
\hline Student to computer ratio & $\sim 0 \%$ \\
\hline Proportion of schools with internet access at school & $\sim 0 \%$ \\
\hline $\begin{array}{l}\text { Proportion of learners who have access to the internet at } \\
\text { school }\end{array}$ & $14 \%$ \\
\hline $\begin{array}{l}\text { Percentage of primary and secondary schools with access to } \\
\text { electricity }\end{array}$ & \\
\hline
\end{tabular}

Table 4. Other Key ICT Indicators ${ }^{4}$

\begin{tabular}{|l|l|}
\hline Fixed-telephone subscriptions per 100 inhabitants & 0.17 \\
\hline Mobile-cellular subscriptions per 100 inhabitants & 56.5 \\
\hline Fixed (wired)-broadband subscriptions per 100 inhabitants & 0.19 \\
\hline Mobile-broadband subscriptions per 100 inhabitants & 11.7 \\
\hline Households with a computer (\%) & 2.58 \\
\hline Households with internet access at home (\%) & 2.96 \\
\hline Individuals using the internet (\%) & 7.98 \\
\hline Households with access to electricity (\%) & $20(2017)$ \\
\hline
\end{tabular}

\footnotetext{
${ }^{3}$ For more information see: UNESCO Institute for Statistics (2015); World Bank (2019); UNESCO Institute for Statistics (2020).

${ }^{4}$ International Telecommunications Union (2018), available at https://www.itu.int/itu-d/apis/clients/res/pdf/country profile/report LBR.pdf ${ }^{5}$ World Bank (2019), available at http://documents.worldbank.org/curated/en/924071562378509179/pdf/Liberia-Improving-Result s-in-Secondary-Education-Project.pdf
} 


\section{Key partners and initiatives in EdTech}

\subsection{Government agencies}

The MoE does not have a department or agency under its purview that is focused on EdTech. The Ministry of Post and Telecommunications is responsible for determining the country's ICT policy and development strategy (Mangesi, 2007). Liberia Telecommunications Authority is the telecom / ICT regulator in Liberia.

\subsection{Non-governmental agencies}

EdTech initiatives have been implemented and supported by key development partners, including the World Bank, USAID, and UNESCO. Key implementing NGO partners include the Rising Academies Liberia, FHI360, Education Development Center (EDC), and Bridge International Academies. Table 5 lists key funding and implementing partners alongside the initiatives they are supporting.

\subsection{EdTech initiatives}

An array of EdTech initiatives, primarily led by donors and international organisations, have been implemented in the past five years. Donors such as the World Bank and USAID have funded programmes with EdTech sub-components linked to interactive radio instruction (IRI), SMS-based communication, and refurbishing classrooms with computer labs and ICT technologies. As part of the Liberia Education Advancement Programme (LEAP), private school operators like Bridge International Academies have used tablets, smartphones and cloud-based technologies to support and monitor teachers. Table 5 highlights recent EdTech initiatives in Liberia.

Table 5. Recent EdTech Initiatives in Liberia

\begin{tabular}{|l|l|}
\hline Name of Initiative & Description \\
\hline Teaching by Radio & \\
$\begin{array}{l}\text { Overview: A radio programme that broadcasts several } \\
\text { pre-recorded lessons a day, each lasting half an hour. Lessons } \\
\text { include English, Mathematics, Reading, History and Social } \\
\text { Studies among others subjects. } \\
\text { Target group: Parents and students at the early childhood and } \\
\text { basic education levels } \\
\text { Technology: Radio and TV broadcast of educational } \\
\text { programmes } \\
\text { Reach / Scale: } 32 \text { radio stations broadcast content } \\
\text { country-wide } \\
\text { Implementing partners: EDC and Rising Academies Liberia } \\
\text { Government partners: Ministry of Education }\end{array}$ \\
\hline
\end{tabular}

${ }^{6}$ Teach by Radio | Ministry of Education (2020), available at http://moe-liberia.org/teach-by-radio/ 


\begin{tabular}{|c|c|}
\hline & Status: 2020 - \\
\hline Rising On Air ${ }^{7}$ & $\begin{array}{l}\text { Overview: Radio programme that provides lessons scripts and } \\
\text { pre-recorded audio content designed specifically for radio and } \\
\text { SMS platforms. } \\
\text { Target group: Parents and students at all education levels } \\
\text { Technology: Radio, SMS, audio files } \\
\text { Reach / Scale: Country-wide. Materials are uploaded online } \\
\text { and free to use } \\
\text { Implementing partners: Rising Academies Liberia, local radio } \\
\text { stations } \\
\text { Government partners: Ministry of Education } \\
\text { Status: } 2020 \text { - }\end{array}$ \\
\hline $\begin{array}{l}\text { Bridge } \\
\text { International } \\
\text { Academies- } \\
\text { Liberian Education } \\
\text { Advancement } \\
\text { Programme (LEAP) }\end{array}$ & $\begin{array}{l}\text { Overview: Public-private partnership that transfers } \\
\text { administrative management of } 92 \text { public schools to a variety of } \\
\text { private and non-profit organisations. Bridge use smartphones, } \\
\text { digital teacher guides and a cloud to deliver standardised } \\
\text { lessons and monitor classroom activities (Bridge International, } \\
\text { 2017). } \\
\text { Target group: Teachers and students in pre-primary and } \\
\text { primary schools } \\
\text { Technology: Tablets, smartphones and cloud-based } \\
\text { technologies. } \\
\text { Reach / Scale: } 170 \text { of the } 236 \text { LEAP public schools across } 10 \text { of } \\
\text { the } 15 \text { counties in Liberia } \\
\text { Implementing partners: Bridge } \\
\text { Government partners: Ministry of Education } \\
\text { Status: } 2016 \text { - }\end{array}$ \\
\hline $\begin{array}{l}\text { Getting to Best in } \\
\text { Education (G2B) }\end{array}$ & $\begin{array}{l}\text { Overview: A basic education project that includes activities for } \\
\text { systems monitoring. Data collection tools (School Quality } \\
\text { Assessment, School Census) developed and digitised and } \\
\text { District Education Officers (DEOs) given tablets and training to } \\
\text { collect real time data. }\end{array}$ \\
\hline
\end{tabular}

\footnotetext{
${ }^{7}$ Rising Academies (2020), available at https://www.risingacademies.com/onair

${ }^{8}$ Bridge International | Liberian Education Advancement Program (2020), available at https://www.bridgeinternationalacademies.com/teaching/government-teachers/liberian-educati on-advancement-program-leap/

${ }^{9}$ Woods Baysah (2018), available at https://www.globalpartnership.org/blog/liberia-launches-getting-best-education-program
} 


\begin{tabular}{|c|c|}
\hline & $\begin{array}{l}\text { Target group: DEOs, Measurement \& Evaluation and } \\
\text { Education Management Information Systems divisions } \\
\text { Technology: Tablets, laptops } \\
\text { Reach / Scale: DEOs will collect data from } 15 \text { counties using } \\
\text { tablets. The M \& E and EMIS team will create and maintain a } \\
\text { database of information collected by DEOs. The team will also } \\
\text { monitor the dashboard and publish content on the MoE } \\
\text { website } \\
\text { Implementing Partners: World Bank, GPE } \\
\text { Government Partner: Ministry of Education } \\
\text { Status: } 2018-2022\end{array}$ \\
\hline $\begin{array}{l}\text { Improving Results } \\
\text { in Secondary } \\
\text { Education (IRISE) }^{10}\end{array}$ & $\begin{array}{l}\text { Overview: A secondary education project. Includes activities to } \\
\text { improve digital skills of students, integrate ICT in teaching, and } \\
\text { identifying and adapting Open Education Resource to the } \\
\text { national curriculum using ICT in teacher training. Project } \\
\text { activities include supporting the development of the national } \\
\text { ICT in education strategy. } \\
\text { Target group: Secondary school students and teachers } \\
\text { Technology: Mobile labs, computer labs, media labs, ICT policy } \\
\text { development, e-platform and app for textbooks } \\
\text { Reach / Scale: Mobile labs will visit selected schools in } \\
\text { Montserrado county (selected based on all-weather roads), } 8 \\
\text { senior secondary schools in Montserrado county for computer } \\
\text { labs, and media lab at the University of Liberia Teaching } \\
\text { College. E-platform and app for textbooks will be open access } \\
\text { and available to all students } \\
\text { Implementing partner: World Bank } \\
\text { Government partner: The Ministry of Education, Ministry of } \\
\text { Postal and Communications, University of Liberia Teachers } \\
\text { College } \\
\text { Status: } 2019-2023\end{array}$ \\
\hline $\begin{array}{l}\text { Economic } \\
\text { Empowerment of } \\
\text { Adolescent Girls } \\
\text { (EPAG) Program }{ }^{11}\end{array}$ & $\begin{array}{l}\text { Overview: The project addressed issues around youth } \\
\text { employment and vulnerability of young women in Liberia } \\
\text { through a life-skills training and employment programme. } \\
\text { While the project itself did not have Ed-Tech components, data } \\
\text { collection for the project, including baseline and end-line }\end{array}$ \\
\hline
\end{tabular}

\footnotetext{
${ }^{10}$ World Bank (2019), available at http://documents.worldbank.org/curated/en/924071562378509179/pdf/Liberia-Improving-Result s-in-Secondary-Education-Project.pdf

${ }^{11}$ Adaho et al. (2014), available at http://documents1.worldbank.org/curated/en/610391468299085610/pdf/WPS6832.pdf
} 


\begin{tabular}{|c|c|}
\hline & $\begin{array}{l}\text { surveys were conducted on tablets. } \\
\text { Target Group: Data enumerators } \\
\text { Technology: Tablets } \\
\text { Reach / Scale: Four data enumerators were trained on } \\
\text { collecting data on tablets and uploading it on the central server } \\
\text { Implementing partner: World Bank, Children's Assistance } \\
\text { Program (CAP) } \\
\text { Government partner: Ministry of Education } \\
\text { Status: } 2017-2018\end{array}$ \\
\hline $\begin{array}{l}\text { Liberia Teacher } \\
\text { Training } \\
\text { Programme } \text { II }^{12}\end{array}$ & $\begin{array}{l}\text { Overview: Teacher-training programme that included } \\
\text { interactive radio instruction (IRI) training modules to better } \\
\text { prepare current teachers and equip new teachers with skills } \\
\text { needed to improve early-grade reading and mathematics. } \\
\text { Target group: Education officials, teachers and parents } \\
\text { Technology: Radio and audio files } \\
\text { Reach / Scale: The programme was implemented in five } \\
\text { counties (Bong, Lofa, Margibi, Montserrado and Nimba). Radio } \\
\text { and audio files developed by RTI are available online. } \\
\text { Implementing partners: FHI360 and USAID } \\
\text { Government partners: Ministry of Education } \\
\text { Status: } 2010-2016\end{array}$ \\
\hline $\begin{array}{l}\text { Advancing Youth } \\
\text { Project }^{13}\end{array}$ & $\begin{array}{l}\text { Overview: Secondary education and TVET programme. During } \\
\text { the Ebola outbreak, the programme delivered educational } \\
\text { programming via radio and used SMS to send class schedules } \\
\text { of the radio programmes. The project also set up a telephone } \\
\text { hotline for students to call in and offer feedback and ask } \\
\text { questions about the radio programmes (UNESCO Institute for } \\
\text { Statistics, 2015: 13). } \\
\text { Target group: Out-of-school youth aged 13-35 with no or } \\
\text { marginal literacy and numeracy skills } \\
\text { Technology: Radio, SMS, Telephone hotline } \\
\text { Reach / Scale:128 lessons were created and broadcasted } \\
\text { throughout the country } \\
\text { Implementing partners: EDC and USAID } \\
\text { Government partners: Ministry of Education, Liberian radio } \\
\text { stations (Hartenberger-Toby, 2020). }\end{array}$ \\
\hline
\end{tabular}

${ }^{12} \mathrm{FHI360} \mathrm{(2016),} \mathrm{available} \mathrm{at}$ https://www.fhi360.org/projects/liberia-teacher-training-program-ii-lttp-ii

${ }^{13}$ Education Development Center (2014), available at https://www.edc.org/advancing-youth-project-interactive-audio-instruction-program-liberia 


\begin{tabular}{|c|c|}
\hline & Status: $2011-2016$ \\
\hline $\begin{array}{l}\text { Enhancing Liberia } \\
\text { Teacher Education } \\
\text { Project through ICT } \\
\text { Pedagogy }^{14}\end{array}$ & $\begin{array}{l}\text { Overview: A digital-skills programme that sought to integrate } \\
\text { ICT in teacher education. } \\
\text { Target group: Teachers, teacher trainees and administration } \\
\text { staff } \\
\text { Technology: Computer labs, ICT training, curriculum } \\
\text { development } \\
\text { Reach / Scale: Teacher Training Institutions (TTIs) at Kakata, } \\
\text { Zorzor, Webbo and the Teachers' College at the University of } \\
\text { Liberia } \\
\text { Implementing partner: UNESCO } \\
\text { Government partner: Teachers' College at the University of } \\
\text { Liberia, Ministry of Education } \\
\text { Status: } 2017\end{array}$ \\
\hline Edify $^{15}$ & $\begin{array}{l}\text { Overview: Programme that provides low-fee private schools } \\
\text { with loans to access education technology for the classroom, } \\
\text { specifically focusing on tools for literacy and critical thinking } \\
\text { skills } \\
\text { Target group: Primary schools } \\
\text { Technology: Computer labs } \\
\text { Reach / Scale: No information } \\
\text { Implementing partners: Edify } \\
\text { Government partners: } \\
\text { Status: } 2013\end{array}$ \\
\hline $\begin{array}{l}\text { Mobile Solutions } \\
\text { Technical } \\
\text { Assistance and } \\
\text { Research (mSTAR) }\end{array}$ & $\begin{array}{l}\text { Overview: A Government of Liberia e-payment programme to } \\
\text { enable digital payment of salaries using mobile money } \\
\text { technologies. } \\
\text { Target group: The programme targets Ministry of Education } \\
\text { employees and teachers } \\
\text { Technology: Mobile money technologies } \\
\text { Reach/Scale: Country-wide. 3,722 MoE officials have enrolled } \\
\text { in the programme. } \\
\text { Implementing partners: FHI360 and USAID } \\
\text { Government partners: Government of Liberia (various } \\
\text { Ministries) }\end{array}$ \\
\hline
\end{tabular}

\footnotetext{
${ }^{14}$ UNESCO (2017), available at https://en.unesco.org/fieldoffice/abuja/teachereducation

${ }^{15}$ Edify (2020), available at https://www.edify.org/liberia/

${ }^{16} \mathrm{FHI360} \mathrm{(2019),} \mathrm{available} \mathrm{at}$
} 
Status: $2011-2016$

With support from partners, the MoE has deployed radio programmes in response to school closures caused by the Ebola epidemic and Covid-19 pandemic (Box 2)

Box 2. Covid-19 leaves 1.4 million students out of classrooms

Schools in Liberia closed on March 16, when the country's first Covid-19 case was confirmed. Within two weeks, the government launched a Teaching by Radio programme to engage students and parents to learn at home. The closure of schools has affected 1.4 million students. Liberia is eligible for a Global Partnership for Education (GPE) Covid-19 emergency response grant of $\$ 10$ million.

\section{Looking Ahead}

Despite the lack of an overarching ICT in Education Policy and poor ICT infrastructure, a variety of EdTech initiatives, primarily led by donors and international organisations, have been implemented in Liberia. Many of these EdTech initiatives were introduced in response to Ebola and Covid-19 or as part of public-private partnerships like LEAP. Analysis of Liberia's use of radio programmes could offer valuable lessons for education programming in emergencies. The Government of Liberia has shown a commitment to EdTech by supporting the development of an ICT in Education policy. The MoE's willingness to adopt innovations such as LEAP, e-payment systems, and investment in digital skills development for the youth, starting from secondary education with the IDA-financed IRISE project demonstrates an openness to the use of ICT in education. Additional research on key EdTech indicators, status and implementation of the ICT in Education Policy, and evaluations of EdTech initiatives is needed for a more comprehensive assessment of the EdTech landscape in Liberia. 


\section{Further reading}

Kaye, T., Groeneveld, C., Moss, C., \& Haßler, B. (2020). Nepal "Ask me anything" Session: Responses to audience questions (EdTech Hub Helpdesk Response No. 13). EdTech Hub.

Moss, C. (2020a, January 22). 18 large-scale EdTech initiatives on our radar in 2020. The EdTech Hub.

Moss, C. (2020b, January 24). 15 EdTech research papers that we share all the time. The EdTech Hub.

Trucano, M. (2013). 10 principles to consider when introducing ICTs into remote, low-income educational environments. https://blogs.worldbank.org/edutech/10-principles-consider-when-introducing-icts -remote-low-income-educational-environments 


\section{References}

Adoho, F., Chakravarty, S., Korkoyah, D. T., Lundberg, M., \& Tasneem, A. (2014). The Impact of an Adolescent Girls Employment Program: The EPAG Project in Liberia. The World Bank.

Andalou Agency. (2019). Delay in teachers' salaries sparks unrest in Liberia. https://www.aa.com.tr/en/africa/delay-in-teachers-salaries-sparks-unrest-in-liberia $\underline{11617043}$

Bridge International. (2017). Learning gains in Liberia. Bridge International Academies. https://www.bridgeinternationalacademies.com/impact/learning-gains-in-liberia/

Bridge International. (2020). Bridge International | Liberian Education Advancement Program (LEAP). Bridge International Academies. https://www.bridgeinternationalacademies.com/teaching/government-teachers/li berian-education-advancement-program-leap/

Edify. (2020). Edify | Liberia. Edify. https://www.edify.org/liberia/

Education Development Center. (2014a). Advancing Youth Project: Interactive Audio Instruction Program in Liberia.

https://www.edc.org/advancing-youth-project-interactive-audio-instruction-progra $\underline{\text { m-liberia }}$

Education Development Center. (2014b). Learning in the Time of Ebola.

https://www.edc.org/learning-time-ebola

FHI360. (2016). Liberia Teacher Training Program II (LTTP II). https://www.fhi360.org/projects/liberia-teacher-training-program-ii-Ittp-ii

FHI360. (2019). Mobile Solutions Technical Assistance and Research (mSTAR). https://www.fhi360.org/projects/mobile-solutions-technical-assistance-and-resear ch-mstar

Front Page Africa. (2019). Liberia: Framework and Strategy Drawn up at UNESCO-MOE ICT in Education Policy Workshop.

https://frontpageafricaonline.com/education/liberia-framework-and-strategy-draw n-up-at-unesco-moe-ict-in-education-policy-workshop/

Government of Liberia. (2019). National ICT Policy (2019-2024). http://www.moci.gov.Ir/doc/ICT\%20 \%20Telecom\%20Policy\%20Main\%20Body.pdf

Hartenberger-Toby, L. (2020). Lessons Learned about Remote Learning from Liberia's Ebola Crisis.

https://www.edc.org/blog/lessons-learned-about-remote-learning-liberias-ebola-cr $\underline{\text { isis }}$

International Telecommunications Union. (2018). Liberia Profile. https://www.itu.int/itu-d/apis/clients/res/pdf/country profile/report LBR.pdf 
Kaye, T., Groeneveld, C., Moss, C., \& Haßler, B. (2020). Nepal "Ask me anything" Session: Responses to audience questions (EdTech Hub Helpdesk Response No. 13). EdTech Hub.

Mangesi, K. (2007). ICT in Education in Liberia (Information for Development). World Bank Group.

Ministry of Education (Liberia). (2016). Getting to Best Education Sector Plan 2017-2021. https://www.globalpartnership.org/sites/default/files/getting to best education s ector plan 2017-2021. liberia.pdf

Ministry of Education (Liberia). (2020). Teach by Radio | Ministry of Education (Liberia). https://moe-liberia.org/teach-by-radio/

Ministry of Finance and Development Planning (Liberia). (2019). MFDP Provides Clarity on Teachers' Salaries Payment. https://www.mfdp.gov.Ir/index.php/media-center/press-release/mfdp-clarifies-mc ss-teachers-september-salary-issues

Moss, C. (2020a, January 22). 18 large-scale EdTech initiatives on our radar in 2020. The EdTech Hub.

https://edtechhub.org/2020/01/22/18-large-scale-edtech-initiatives-on-our-radar-i n-2020/

Moss, C. (2020b, January 24). 15 EdTech research papers that we share all the time. The EdTech Hub.

Rising Academies. (2020). Rising On Air. https://www.risingacademies.com/onair

Sarpong, E. (2016). Liberia ICT Policy 2017-2021: Initial Stakeholders Consultation. Alliance for Affordable Internet.

Trucano, M. (2013). 10 principles to consider when introducing ICTs into remote, low-income educational environments.

https://blogs.worldbank.org/edutech/10-principles-consider-when-introducing-icts -remote-low-income-educational-environments

UNESCO. (2017). Enhancing Liberia Teacher Education Project through ICT Pedagogy. https://en.unesco.org/fieldoffice/abuja/teachereducation

UNESCO Institute for Statistics. (2015). Information and Communication Technology (ICT) in Education in sub-Saharan Africa: A comparative analysis of basic e-readiness in schools. Information Paper No. 25.

UNESCO Institute for Statistics. (2016). ICT in education statistics: Shifting from regional reporting to global monitoring;progress made, challenges encountered, and the way forward. https://unesdoc.unesco.org/ark:/48223/pf0000245572

UNESCO Institute for Statistics. (2020a). Education | Liberia. http://data.uis.unesco.org/Index.aspx?queryid=156

UNESCO Institute for Statistics. (2020b). International Standard Classification of Education (ISCED). 
http://uis.unesco.org/en/topic/international-standard-classification-education-isce d

Wilkins, D. (2019). Liberia: Farewell 2019 - A Review of ICT Initiatives in Liberia. All Africa. https://allafrica.com/stories/201912310442.html

Woods Baysah, D. (2018). Liberia launches "getting to best in education" program. Global Partnership for Education.

https://www.globalpartnership.org/blog/liberia-launches-getting-best-education-pr ogram

World Bank. (2016). Liberia Education Sector Analysis.

http://documents1.worldbank.org/curated/en/481011575583469840/pdf/Liberia-E ducation-Sector-Analysis.pdf

World Bank. (2018). From Growth to Development: Priorities for Sustainably Reducing Poverty and Achieving Middle-Income Status by 2030.

http://documents.worldbank.org/curated/en/585371528125859387/pdf/LBR-SCDdraft-10-06012018.pdf

World Bank. (2019). Liberia-Improving Results in Secondary Education Project. http://documents.worldbank.org/curated/en/924071562378509179/pdf/Liberia-Im proving-Results-in-Secondary-Education-Project.pdf 